\title{
SIANALISIS RASIO KEUANGAN PERBANKAN TERHADAP KINERJA KEUANGAN DENGAN SUKU BUNGA SEBAGAI MODERASI
}

\author{
Alfred Kristanto \\ Program Studi Maksi Fakultas Ekonomi Universitas Tarumanagara, Jakarta \\ Email: alfred.kristanto@gmail.com
}

\begin{abstract}
This study was conducted to analyze the effect of loan to deposit ratio, operating income, operating expense, economic value added, return on asset, and capital adequacy ratio on Stock Return with interest rate of Bank of Indonesia as moderating variable. Population used in this research is banking sector issuer listed in Indonesia Stock Exchange year 2012-2016. Data was processed using SPSS version 24.0, while moderated regression analysis was used in testing. Result indicates that loan to deposit ratio, operating income, operating expense, and capital adequacy ratio influence on stock return. Meanwhile, economic value added and return on assets have no effects on stock return. Simultaneously, loan to deposit ratio, operating expense, operating income, economic value added, return on asset, and capital adequacy ratio affect stock return.
\end{abstract}

Keywords : Bank Financial Ratio, Financial Performance, Interest Rate, Stock Return, Deposit Ratio.

\begin{abstract}
ABSTRAK
Penelitian ini untuk menganalisis pengaruh loan to deposit ratio, beban operasional pendapatan operasional, economic value added, return on asset, dan capital adequacy ratio terhadap return saham dengan suku bunga bank indonesia sebagai variabel moderasi. Populasi yang digunakan dalam penelitian ini adalah emiten sektor perbankan yang terdaftar di Bursa Efek Indonesia tahun 2012-2016. Pengolahan data menggunakan SPSS versi 24.0 pengujian menggunakan moderated regression analysis. Hasil penelitian menujukkan loan to deposit ratio, beban operasional pendapatan operasional, dan capital adequacy ratio berpengaruh terhadap return saham. Sedangkan, economic value added dan return on assets tidak memiliki pengaruh terhadap return saham. Secara bersama-sama loan to deposit ratio, beban operasional pendapatan operasional, economic value added, return on asset, dan capital adequacy ratio berpengaruh terhadap return saham.
\end{abstract}

Kata kunci: Rasio Keuangan Perbankan, Kinerja Keuangan, Suku Bunga, Return Saham

\section{PENDAHULUAN}

\section{Latar Belakang}

Mengetahui kondisi kesehatan perusahaan juga sangat penting dilakukan oleh investor, bankers, maupun kreditor dalam pengambilan keputusan-keputusan investasi dan kreditnya. Mereka adalah pihak-pihak yang berkepentingan terhadap keuntungan perusahaan di masa yang akan datang, perkembangan perusahaan dan untuk mengetahui jaminan investasinya serta kondisi kerja atau kondisi keuangan jangka pendek perusahaan tersebut.

Dari hasil analisa laporan keuangan tersebut, investor, bank, dan kreditur akan dapat menentukan langkah-langkah yang harus ditempuhnya. Pemerintah sangat berkepentingan terhadap laporan keuangan perusahaan, di samping itu untuk menentukan besarnya pajak yang harus ditanggung oleh perusahaan juga sangat diperlukan oleh Badan Pusat Statistik (BPS), Dinas Perindustrian, Perdagangan dan Tenaga Kerja sebagai dasar perencanaan pemerintah di masa yang akan datang.

Krisis ekonomi global merupakan peristiwa dimana seluruh sektor ekonomi pasar dunia mengalami keruntuhan dan mempengaruhi sektor lainnya di seluruh dunia. Ini dapat kita lihat bahwa negara adidaya yang memegang kendali ekonomi pasar dunia yang mengalami keruntuhan besar dari sektor ekonominya. Analisis rasio keuangan merupakan suatu alternatif untuk menguji apakah informasi keuangan yang dihasilkan oleh akuntansi keuangan bermanfaat untuk melakukan klasifikasi atau prediksi terhadap harga saham di pasar modal. 
Fenomena yang terjadi pada dewasa ini adalah adanya kewaspadaan Bank Indonesia terhadap beberapa sektor yang dinilai berpotensi memiliki tingkat kredit macet (non performing loan/NPL). NPL perbankan tercatat sebesar 2,6 persen, naik 0,1 persen dibandingkan bulan sebelumnya yang di level 2,5 persen. Secara umum kualitas likuiditas perbankan dan pertumbuhan kreditnya ada di atas 10 persen, rasio kecukupan modal mencapai 20 persen.

Berdasarkan pemikiran-pemikiran bahwa investor memerlukan informasi untuk memilih tempat untuk menginvestasikan dananya yang berkaitan dengan kondisi perusahaan dan berdasarkan penelitian terdahulu yang menunjukkan hasil yang kurang konsisten, maka dilakukan pengkajian dan penelitian kembali dengan topik serupa..

Penelitian ini dilakukan untuk meneliti dan melengkapi bukti empiris, mengkaji dan menjelaskan besarnya pengaruh loan to deposit ratio, beban operasional pendapatan operasional, economic value added, return on asset, dan capital adequacy ratio terhadap return saham dengan suku bunga bank indonesia sebagai variabel moderasi pada emiten sektor perbankan yang terdaftar di bursa efek indonesia tahun 2012-2016, baik secara masing-masing maupun secara bersamaan.

\section{Kajian Teori}

Business entity concept atau dalam literatur-literatur teori akuntansi dikenal dengan entity theory menyatakan bahwa kepemilikan aset dimiliki oleh perusahaan dan antara kewajiban dengan pemegang ekuitas oleh investor dalam aset tersebut merupakan hak yang berbeda. Atas dasar konsep ini, maka dapat dirumuskan dalam posisi keuangan atau neraca bahwa aset sama dengan jumlah kewajiban ditambah dengan ekuitas pemilik. Menurut Aulia dan Havidz (2013) teori perusahaan pada mulanya, perusahaan dipandang sebagai usaha yang bertujuan untuk memaksimalisasi laba sebagai sasaran utamanya, yaitu pemilik dan manajer perusahaan diasumsikan berusaha memaksimumkan laba jangka pendek perusahaan. Sasaran memaksimalisasi nilai yang diharapkan sekarang dipandang sebagai tujuan utama bisnis dalam teori.

Menurut Brigham \& Houston (2006), para manajer (agent) diberikan wewenang oleh pemilik perusahaan (principal) untuk membuat keputusan. Hal ini dapat menimbulkan konflik kepentingan yang dikenal sebagai teori keagenan (agency theory). Menurut Jensen dan Meckling (1976), hubungan keagenan adalah sebuah kontrak yang terjadi antara manajer (agent) dengan pemilik (principal). Hubungan kontraktual terjadi ketika pemilik memberikan otoritas pembuatan keputusan kepada manajer. Konflik kepentingan antara agent dengan principal terjadi karena adanya kemungkinan agent tidak selalu berbuat sesuai dengan apa yang diinginkan atau kepentingan principal yang pada akhirnya menimbulkan biaya keagenan (agency cost).

Teori keagenan dilandasi oleh beberapa asumsi (Eisenhardt, 1989). Asumsi-asumsi tersebut dibedakan menjadi tiga jenis, yaitu asumsi tentang sifat manusia, asumsi keorganisasian, dan asumsi informasi. Asumsi tentang sifat dasar manusia menekankan bahwa manusia memiliki sifat mementingkan dirinya sendiri (self-interest), memiliki keterbatasan rasional, dan tidak menyukai risiko. Asumsi keorganisasian adalah konflik yang terjadi di antara anggota organisasi, efisiensi sebagai kriteria efektivitas, dan adanya asymmetric information antara agent dan principal. Asumsi informasi maksudnya adalah informasi sebagai barang dagang yang dapat diperjualbelikan.

Menurut IAI (2009) kinerja keuangan adalah kemampuan perusahaan dalam mengelola dan mengendalikan sumberdaya yang dimilikinya. Hobarth (2006) meneliti hubungannya antara indikator keuangan dan kinerja perusahaan perusahaan yang terdaftar di Amerika Serikat selama 19 tahun dengan menggunakan 17 indikator keuangan. Hasilnya menunjukkan bahwa 
perusahaan dengan rasio book to market yang rendah, efisiensi manajemen modal kerja, likuiditas rendah, ekuitas lebih banyak dan memiliki liabilitas yang lebih sedikit, dan laba ditahan yang tinggi seta memiliki earning before tax (EBT) yang tinggi, memiliki kinerja pasar yang lebih baik (diukur dengan perubahan dalam harga saham).

Menurut Jones (2000), return adalah yield dan capital gain (loss). Yield adalah arus kas yang dibayarkan secara periodik kepada pemegang saham (dalam bentuk dividen), sedangkan capital gain (loss), yaitu selisih antara harga saham pada saat pembelian dengan harga saham pada saat penjualan. Hal tersebut diperkuat oleh Corrado dan Jordan (2000) yang menyatakan bahwa return dari investasi yang diperjualbelikan dapat berupa cash flow dan capital gain (loss). Jika tidak adanya tingkat keuntungan yang diperoleh dari suatu investasi, maka pemilik modal tidak akan melakukan investasi. Komponen return terdiri dari dua jenis yaitu current income (pendapatan lancar) dan capital gain (keuntungan selisih harga). Pengertian loan to deposit ratio menurut Peraturan Bank Indonesia Nomor 15/7/PBI/2013 Tentang Giro Wajib Minimum Bank Umum pada Bank Indonesia dalam Rupiah dan Valuta Asing adalah rasio kredit yang diberikan kepada pihak ketiga dalam Rupiah dan valuta asing, tidak termasuk kredit kepada Bank lain, terhadap dana pihak ketiga yang mencakup giro, tabungan, dan deposito dalam Rupiah dan valuta asing, tidak termasuk dana antar Bank.

Kasmir (2012) mengartikan loan to deposit ratio merupakan rasio untuk mengukur komposisi jumlah kredit yang diberikan dibandingkan dengan jumlah dana masyarakat dan modal sendiri yang digunakan. Sedangkan menurut Sipahutar (2007), loan to deposit ratio merupakan perbandingan antara kredit yang disalurkan perbankan terhadap penghimpunan dana pihak ketiga. Dendawijaya (2001) mengartikan loan to deposit ratio adalah seberapa jauh kemampuan bank dalam membiayai kembali penarikan dana yang dilakukan dengan mengandalkan kredit yang diberikan sebagai sumber likuiditasnya.

Beban operasional pendapata operasional merupakan rasio antara biaya operasi terhadap pendapatan operasi. Rasio BOPO digunakan untuk mengukur tingkat efisiensi dan kemampuan bank dalam melakukan kegiatan operasional (Lukman D Wijaya, 2000). Biaya operasi merupakan biaya yang dikeluarkan oleh bank dalam rangka menjalankan aktivitas usaha utamanya seperti biaya bunga, biaya pemasaran, biaya tenaga kerja, dan biaya operasi lainnya. Pendapatan operasi merupakan pendapatan utama bank yaitu pendapatan yang diperoleh dari penempatan dana dalam bentuk kredit dan pendapatan operasi lainnya. Semakin kecil BOPO menunjukkan semakin efisien bank dalam menjalankan aktivitas usahanya. Menurut ketentuan Bank Indonesia efisiensi operasi suatu bank dapat diukur dengan BOPO.

Menurut Merton H. Miller dan Franco Modiglani (1961) mengatakan bahwa laba ekonomis (economic income) merupakan sumber penciptaan nilai (value creation) sedangkan tingkat pengembalian (rate of return) ditentukan oleh besarnya resiko yang diasumsikan oleh investor. Pada dasarnya EVA adalah laba yang tertinggal setelah dikurangi dengan biaya modal yang diinvestasikan (Tunggal, 2008). Metode ini menciptakan suatu disiplin keuangan yang mendorong para manajer untuk bertindak sebagai pemilik perusahaan, dan satu hal yang terpenting adalah untuk meningkatkan profit bagi shareholders. EVA adalah salah satu alat ukur untuk menilai kinerja keuangan perusahaan. EVA mengukur perbedaan antara laba pada suatu modal perusahaan dan biaya modal.

Menurut Brigham dan Houston (2001), Rasio laba bersih terhadap total aktiva mengukur pengembalian atas total aktiva setelah bunga dan pajak. Menurut Horne dan Wachowicz (2005), ROA mengukur efektivitas keseluruhan dalam menghasilkan laba melalui aktiva yang tersedia, daya untuk menghasilkan laba dari modal yang diinvestasikan. Horne dan Wachowicz 
menghitung ROA dengan menggunakan rumus laba bersih setelah pajak dibagi dengan total aktiva. Bambang Riyanto (2001) menyebut istilah ROA dengan Net Earning Power Ratio (Rate of Return on Investment) yaitu kemampuan dari modal yang diinvestasikan dalam keseluruhan aktiva untuk menghasilkan keuntungan bersih.

Capital Adequacy Ratio menurut Lukman Dendawijaya (2000) adalah rasio yang memperlihatkan seberapa jauh seluruh aktiva bank yang mengandung risiko (kredit, penyertaan, surat berharga, dan tagihan pada bank lain). Capital Adequacy Ratio (CAR) atau rasio permodalan adalah modal dasar yang harus dipenuhi oleh bank. Rasio ini digunakan untuk membuat masyarakat percaya terhadap kinerja bank. Faktor yang mempengaruhi jumlah modal sebuah bank adalah jumlah modal minimum yang ditentukan oleh wewenang bank sentral dan dalam hal ini adalah Bank Indonesia.

Tingkat suku bunga sangatlah penting, karena setiap orang mengharapkan hasil investasi yang lebih besar termasuk juga para investor saham. Dengan danya perubahan tingkat suku bunga maka tingkat pengembalian hasil berbagai macam investasi juga akan mengalami perubahan. Suku bunga ini adalah suku bunga yang ditetapkan oleh Bank Indonesia (BI) selaku Bank Sentral dengan mengeluarkan Sertifikat Bank Indonesia (SBI). Menurut Sugeng Raharjo (2010), tingkat suku bunga merupakan daya tarik bagi investor untuk menanamkan investasinya dalam bentuk deposito atau SBI sehingga investasi dalam bentuk saham akan tersaingi.

Kerangka pemikiran dalam penelitian ini seperti digambarkan dibawah ini:

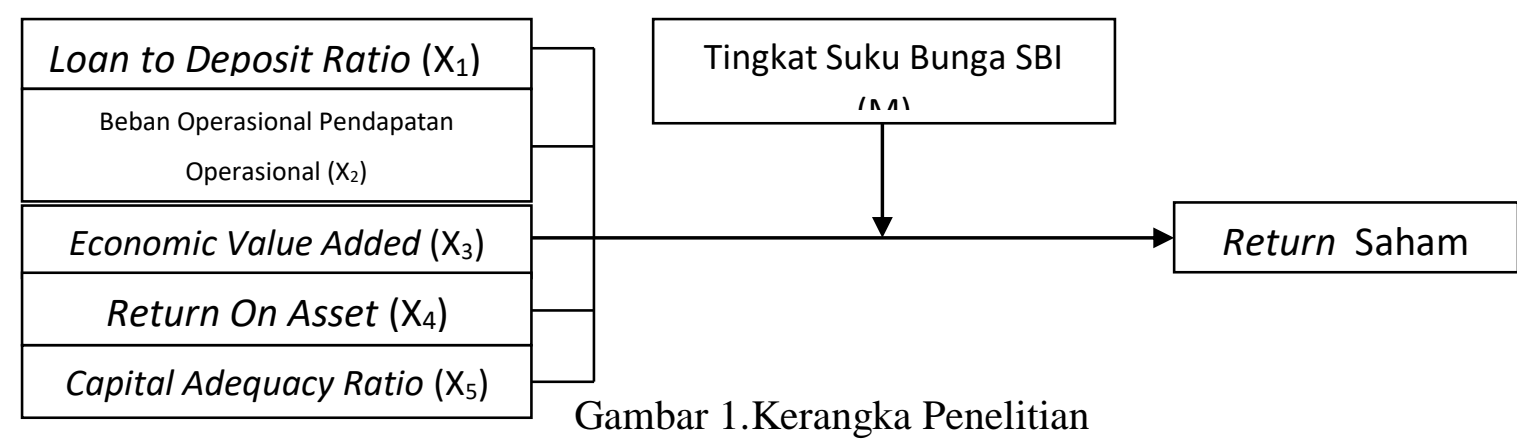

Hipotesis dari model yang dibangun di atas adalah sebagai berikut :

$H_{1}$ : Loan to Deposit Ratio berpengaruh signifikan positif terhadap Return Saham.

$\mathrm{H}_{2}$ : Beban Operasional dan Pendapatan Operasional berpengaruh signifikan negatif terhadap Return Saham.

$H_{3}$ : Economic Value Added berpengaruh signifikan positif terhadap Return Saham.

$H_{4}$ : Return On Asset berpengaruh signifikan negatif terhadap Return Saham.

$H_{5}$ : Capital Adequacy Ratio berpengaruh signifikan negatif terhadap Return Saham.

$H_{6}$ : Loan to Deposit Ratio berpengaruh signifikan negatif terhadap Return Saham dengan Tingkat Suku Bunga Bank Indonesia sebagai moderasi.

$H_{7}$ : Beban Operasional Pendapatan Operasional berpengaruh signifikan positif terhadap Return Saham dengan Tingkat Suku Bunga Bank Indonesia sebagai moderasi.

$H_{8}$ : Economic Value Added berpengaruh signifikan negatif terhadap Return Saham dengan Tingkat Suku Bunga Bank Indonesia sebagai moderasi.

$H_{9}$ : Return On Asset berpengaruh signifikan positif terhadap Return Saham dengan Tingkat Suku Bunga Bank Indonesia sebagai moderasi. 


\section{$H_{10}$ : Capital Adequacy Ratio berpengaruh signifikan negatif terhadap Return Saham dengan Tingkat Suku Bunga Bank Indonesia sebagai moderasi.}

\section{METODE PENELITIAN}

Populasi yang digunakan dalam penelitian ini mencakup 41 emiten yang sudah terdaftar dan tercatat dalam sektor perbankan yang berada di Bursa Efek Indonesia tahun 2012-2016. Metode yang digunakan dalam penulisan tesis ini adalah metode penelitian deskriptif dengan menggunakan pendekatan kuantitatif yaitu penelitian yang kemudian diolah dan dianalisis untuk diambil kesimpulan. Penelitian ini menggunakan desain penelitian data panel yang menggabungkan data cross-section dan time-series. Data yang diteliti merupakan data sekunder yang diperoleh dari berbagai sumber, baik dari website perusahaan dan website Bursa Efek Indonesia. Data yang telah terkumpul akan diolah dengan menggunakan SPSS versi 24.

Setelah adanya batasan populasi, populasi yang termasuk dalam kriteria yang telah ditetapkan hanya berjumlah 203 pengamatan penelitian dari total 215 pengamatan penelitian. Kemudian, dari populasi ditarik sampel dimana sampel merupakan bagian dari populasi. Teknik pengambilan sampel yang digunakan ialah simple-random sampling yaitu teknik pengambilan sampel secara acak. Tujuan dari simple-random sampling adalah untuk memberikan kesempatan yang sama kepada setiap unit sampel dalam unsur populasi untuk dijadikan sampel yang dapat mewakili populasi. Variabel dependen dalam penelitian ini adalah return saham. Variabel independen dalam penelitian ini terdiri dari loan to deposit ratio, beban operasional pendapatan operasional, economic value added, return on asset, dan capital adequacy ratio. Dan, variabel moderasi dalam penelitian ini adalah suku bunga Bank Indonesia.

Return saham ialah hasil yang diperoleh dari suatu investasi (Jogianto, 2010). Untuk menghitung return saham digunakan rumus sebagai berikut (Hartono, 2009), yaitu:

$$
\text { Return Saham }=\frac{\mathrm{Pt}-\mathrm{Pt}-1}{\mathrm{Pt}-1}
$$

Loan to Deposit Ratio (LDR) merupakan rasio yang digunakan untuk mengukur total kredit terhadap total dana pihak ketiga yang dibagikan dalam bentuk kredit. LDR dapat dihitung dengan formula: (Sesuai SE No.6/23/DPNP Tanggal 31 Mei 2004).

$$
\mathrm{LDR}=\frac{\text { Total Kredit }}{\text { Dana Pihak Ketiga }} \times 100 \%
$$

Beban operasional pendapatan operasional (BOPO) adalah rasio yang membandingkan antara beban-beban operasional dengan pendapatan operasional. Menurut Taswan (2010) rasio BOPO dapat dirumuskan sebagai berikut:

$$
\mathrm{BOPO}=\frac{\text { Total Beban Operasional }}{\text { Total Pendapatan Operasional }} \quad \mathrm{x} 100 \%
$$

Economic Value Added (EVA) merupakan sebuah ukuran laba ekonomis yang dapat ditentukan dari selisih antara Laba Bersih Operasional Setelah Pajak (Net Operating Profit After Tax) dengan biaya Modal. Biaya modal ini ditentukan melalui biaya rata-rata tertimbang dari Hutang dan Ekuitas (Weighted Average Cost of Debt and Equity Capital-WACC) dan jumlah dari modal yang digunakan (Stewart, 2010). 


\begin{tabular}{|c|c|}
\hline Tahapan & $\begin{array}{c}\text { Perhitungan } \\
\end{array}$ \\
\hline 1. NOPAT & NOPAT = Laba Bersih + Biaya Bunga \\
\hline \multirow[t]{3}{*}{ 2. $\left(\mathrm{Kd}^{*}\right)$} & $K d=\underline{\text { Biaya bunga }}$ \\
\hline & hutang \\
\hline & $\mathrm{Kd}^{*}=\mathrm{Kd}(1-\mathrm{T})$ \\
\hline 1. (Ke) & $K e=R_{f}+\beta\left(R_{m}-R_{f}\right)$ \\
\hline \multirow[t]{4}{*}{ 2. Struktur Modal } & Wd $=\underline{\text { Hutang }}$ \\
\hline & Aset \\
\hline & We $=\underline{\text { Ekuitas }}$ \\
\hline & Aset \\
\hline 3. WACC & $W A C C=\left[\left(K^{*} W_{d}\right)+(K e \times W e)\right]$ \\
\hline 4. IC & IC $=$ Asset - Non Interest Liabilities \\
\hline 5. $\operatorname{coc}$ & $C O C=W A C C \times I C$ \\
\hline 6. EVA & $E V A=N O P A T-C O C$ \\
\hline
\end{tabular}

Return on Asset atau disebut juga rentabilitas ekonomi ialah laba usaha dengan modal sendiri dan modal asing yang dipergunakan untuk menghasilkan laba tersebut dan dinyatakan dalam persentase. Menurut Weston dan Brigham (1990), rumus untuk menghitung ROA adalah sebagai berikut:

$\mathrm{ROA}=\frac{\text { Laba Bersih (EAT) }}{\text { Total Aset }} \times 100 \%$

Capital Adequacy Ratio (CAR) adalah rasio yang memperlihatkan seberapa jauh seluruh aktiva bank yang mengandung resiko (kredit, penyertaan, surat berharga, tagihan pada bank lain) ikut dibiayai dari dana modal sendiri bank di samping memperoleh dana-dana dari sumbersumber di luar bank, seperti dana masyarakat, pinjaman (utang), dan lain-lain. (Lukman Dendawijaya, 2009). CAR dapat dihitung dengan metode perhitungan sebagai berikut (Agus Sartono, 2008):

$$
\mathrm{CAR}=\frac{\text { Modal }}{\text { Aktiva Tertimbang Menurut Risiko }} \times 100 \%
$$

Variabel moderasi yang digunakan dalam penelitian ini adalah suku bunga Bank Indonesia yang didapat dari website Bank Indonesia.

Penelitian ini menggunakan Uji Statistik Deskriptif untuk menguji data sampel, kemudian melakukan uji asumsi klasik yang terdiri dari Uji Normalitas, Uji Multikolinieritas, Uji Heterokedastisitas, dan Uji Autokorelasi. Untuk uji hipotesis, penelitian ini menggunakan Uji t, Uji F, dan Uji Koefisien Determinasi Berganda $\left(\mathrm{R}^{2}\right)$.

\section{HASIL DAN PEMBAHASAN}

Uji statistik deskriptif menggambarkan tentang ringkasan data penelitian seperti nilai minimum, nilai maksimum, mean dan standar deviasi. Loan to deposit ratio (LDR) memiliki nilai minimum 0,065 , nilai maksimum 1,40720 , rata-rata sebesar $84,37 \%$ dengan standar deviasi $18,27 \%$. Dapat dilihat bahwa rata-rata LDR emiten perbankan di Indonesia telah sesuai dengan Peraturan Bank Indonesia Nomor 15/15/PBI/2013 bahwa batas aman loan to deposit ratio berkisar antara $78 \%$ sampai dengan $92 \%$. Beban operasional pendapatan operasional (BOPO) memiliki nilai minimum 0,3244, nilai maksimum 2,352, rata-rata sebesar $86,09 \%$ dengan standar deviasi 18,33\%. Dapat dilihat bahwa rata-rata BOPO emiten perbankan di Indonesia sudah cukup baik memiliki nilai lebih dari $80 \%$. Economic value added (EVA) memiliki nilai minimum -1, nilai maksimum 1, rata-rata sebesar 97,07\% dengan standar deviasi 33\%. Dapat dilihat bahwa rata-rata EVA emiten perbankan di Indonesia memiliki EVA positif (>0), yang berarti bahwa tingkat pengembalian yang dihasilkan lebih besar daripada biaya modalnya atau terdapat nilai ekonomis ke dalam perusahaan selama operasionalnya. Return on Asset (ROA) sebesar $1,77 \%$, memiliki nilai minimum $-0,1115$, nilai maksimum 0,52 , dengan standar deviasi 
41,85\%. Hal ini berarti rata-rata sampel yang digunakan memiliki ROA yang positif, semakin positif ROA, maka secara otomatis perusahaan memiliki lebih banyak dana untuk kegiatan operasional dan akan meningkatkan pula return saham bagi para pemegang saham. Capital adequacy ratio (CAR) memiliki nilai minimum 0,0682 , nilai maksimum 0,87490 , rata-rata sebesar 20,01\% dengan standar deviasi 4,77\%. Dapat dilihat bahwa rata-rata CAR emiten perbankan di Indonesia memiliki CAR yang rendah, semakin besar biaya modal yang digunakan maka akan memperkecil biaya operasional yang nantinya akan menimbulkan keuntungan pajak dan akan meningkatkan return saham yang diterima oleh para pemegang saham. Suku bunga Bank (SBI) Indonesia memiliki nilai minimum 0,5583, nilai maksimum 0,07542, rata-rata sebesar 6,57\% dengan standar deviasi $12,03 \%$. Dapat dilihat bahwa rata-rata suku bunga Bank Indonesia sudah cukup baik, karena memiliki nilai yang tidak terlalu fluktuatif, sehingga tidak akan menimbulkan ketimpangan pada data yang digunakan.

Uji Asumsi Klasik. Sebelum dilakukan pengujian hipotesis, terlebih dahulu dilakukan uji asumsi klasik pada model regresi.

Uji Normalitas. Penelitian ini menggunakan uji normalitas dengan One-sample Kolmogorov-Smirnov. Hasil penelitian ini menunjukkan nilai sig.(2-tailed) sebesar $0.200>0.05$ yang berarti data berdistribusi normal dan model regresi telah memenuhi asumsi normalitas.

Uji Multikolinieritas. Digunakan untuk menguji ada tidaknya multikolinieritas, dilihat dari nilai tolarance atau VIF. Dari hasil pengolahan data, diperoleh nilai tolerance $>0,10$ dan nilai VIF $<10$ untuk semua variabel maka persamaan model regresi tidak mengandung masalah multikolinieritas.

Uji Autokorelasi. Digunakan untuk menguji ada tidaknya masalah autokorelasi dimana dari hasil pengolahan data diperoleh nilai sig sebesar1,685. Angka tersebut terletak diantara nilai dU $(1,8226)$ dan nilai 4-dU $(2,1774)$, sehingga dapat disimpulkan bahwa persamaan model regresi tidak terjadi masalah autokorelasi.

Uji Heterokedastisitas. Digunakan untuk melihat ada tidaknya heteroskedastisitas, dilihat dari nilai signifikansinya dimana hasil pengolahan dalam penelitian ini menunjukkan nilai signifikansi $>0.05$ untuk semua variabel. Maka, persamaan model regresi tidak mengandung masalah heterokedastisitas.

Uji F (simultan) adalah uji yang digunakan untuk mengetahui apakah variabel independen secara bersama-sama memiliki pengaruh terhadap variabel dependen dan untuk mengetahui apakah model persamaan regresi berganda layak untuk digunakan. Berdasarkan hasil pengolahan data, diketahui bahwa variabel independen memiliki pengaruh terhadap variabel dependen karena memiliki nilai signifikansi yang lebih besar dari 0,009. Hasil uji ini dapat dilihat pada tabel dibawah ini:

Tabel 1. Uji F-ANOVA

\begin{tabular}{|c|c|c|c|c|c|c|}
\hline & \multicolumn{6}{|c|}{ ANOVA $^{a}$} \\
\hline & Model & Sum of Squares & $\mathrm{df}$ & Mean Square & $\mathrm{F}$ & Sig. \\
\hline \multirow[t]{3}{*}{1} & Regression & ,001 & 11 &, 000 & 2,386 &, $009^{\mathrm{b}}$ \\
\hline & Residual &, 005 & 158 &, 000 & & \\
\hline & Total & ,006 & 169 & & & \\
\hline
\end{tabular}

a. Dependent Variable: RE

b. Predictors: (Constant), CARSBI, ROA, EVA, BOPO, LDR, SBI, LDRSBI, CAR, BOPOSBI, EVASBI, ROASBI 
Untuk mengetahui korelasi variabel-variabel independen terhadap variabel dependen, maka dilakukan uji koefisien korelasi (R). Berdasarkan hasil pengolahan data, didapatkan nilai $\mathrm{R}$ sebesar 0,477. Dengan demikian dapat disimpulkan bahwa hubungan antara variabel independen dengan variabel dependen yang dimoderasi dengan Suku Bunga Bank Indonesia yaitu adalah sedang. Hasil uji koefisien determinasi menunjukkan nilai Adjusted $\mathrm{R}^{2}$ sebesar 0,283 artinya secara statistik besarnya variasi dari variabel Return Saham yang dapat dijelaskan oleh variabel independen sebesar 28,3\% dan sisanya $71,7 \%$ dipengaruhi oleh faktor-faktor lain yang tidak terdapat dalam model penelitian ini. Hasil uji ini dapat dilihat pada tabel dibawah ini:

Tabel 2. Uji Koefisien Determinasi

\begin{tabular}{|c|c|c|c|c|c|}
\hline \multirow[b]{2}{*}{ Model } & \multirow[b]{2}{*}{$\mathrm{R}$} & \multicolumn{3}{|c|}{ Model Summary ${ }^{b}$} & \multirow[b]{2}{*}{ Durbin-Watson } \\
\hline & & R Square & $\begin{array}{c}\text { Adjusted R } \\
\text { Square } \\
\end{array}$ & $\begin{array}{c}\text { Std. Error of the } \\
\text { Estimate }\end{array}$ & \\
\hline 1 &, $477^{\mathrm{a}}$ & ,142 & ,283 &, 00570836 & 1,581 \\
\hline
\end{tabular}

a. Predictors: (Constant), CARSBI, ROA, EVA, BOPO, LDR, SBI, LDRSBI, CAR, BOPOSBI,

EVASBI, ROASBI

b. Dependent Variable: RE

Uji t (parsial) adalah uji yang digunakan untuk menguji keterkaitan secara individu antara variabel bebas dengan variabel terikat. Untuk menguji hipotesis nol ditolak atau diterima, titik tolaknya adalah bila nilai $p$-value $t$-test $<$ atau $>0,05$, artinya jika nilai signifikansi dari variabel independen di bawah 0,05, maka $\mathrm{H}_{0}$ ditolak dan $\mathrm{H}_{1}$ diterima dan sebaliknya. Berdasarkan hasil pengolahan data, diketahui bahwa variabel economic value added dan return on assets tidak memiliki pengaruh terhadap return saham karena memiliki nilai signifikansi dibawah 0,05. Sebaliknya, loan to deposit ratio, beban operasional pendapatan operasional, dan capital adequacy ratio berpengaruh terhadap return saham karena memiliki nilai signifikansi diatas 0,05. Hasil uji ini dapat dilihat pada tabel dibawah ini:

Tabel 3. Uji Hipotesis

\begin{tabular}{|c|c|c|c|c|c|c|}
\hline & \multicolumn{6}{|c|}{ Coefficients $^{a}$} \\
\hline & \multirow[b]{3}{*}{ Model } & \multirow{2}{*}{\multicolumn{2}{|c|}{ Unstandardized Coefficients }} & \multirow{3}{*}{$\begin{array}{c}\text { Standardized } \\
\text { Coefficients } \\
\text { Beta } \\
\end{array}$} & \multirow[b]{3}{*}{$\mathrm{t}$} & \multirow[b]{3}{*}{ Sig. } \\
\hline & & & & & & \\
\hline & & $\mathrm{B}$ & Std. Error & & & \\
\hline \multirow[t]{12}{*}{1} & (Constant) &, 000 &, 003 & &,- 134 &, 893 \\
\hline & LDR &, 042 &, 022 & 1,273 & 1,891 &, 040 \\
\hline & BOPO &,- 031 &, 022 &,- 358 & $-1,434$ &, 044 \\
\hline & EVA &, 002 &, 013 &, 134 & ,193 &, 847 \\
\hline & ROA &,- 259 &, 181 & $-1,821$ & $-1,430$ & ,155 \\
\hline & CAR &,- 027 &, 087 &,- 214 &,- 307 &, 048 \\
\hline & SBI &, 168 &, 099 &, 340 & 1,704 &, 040 \\
\hline & LDRSBI &,- 628 &, 340 & $-1,486$ & $-1,850$ &, 046 \\
\hline & BOPOSBI &, 363 &, 357 &, 883 & 1,018 &, 010 \\
\hline & EVASBI &,- 012 &, 183 &,- 048 &,- 066 & ,347 \\
\hline & ROASBI & 4,785 & 3,207 & 1,931 & 1,492 &, 138 \\
\hline & CARSBI &,- 078 & 1,280 &,- 047 &,- 061 &, 049 \\
\hline
\end{tabular}

a. Dependent Variable: RE 


\section{Diskusi}

Berdasarkan hasil pembahasan mengenai pengaruh loan to deposit ratio, beban operasional pendapatan operasional, economic value added, return on asset, dan capital adequacy ratio terhadap return saham dengan suku bunga Bank Indonesia sebagai variabel moderasi. Maka dapat ditarik kesimpulan sebagai berikut, loan to deposit ratio berpengaruh signifikan positif terhadap return saham. Bahwa semakin besar persentase loan to deposit ratio maka akan meningkatkan return saham. semakin besar risiko maka semakin besar pula return saham yang akan didapatkan. Semakin besar pinjaman yang didapatkan, maka semakin besar dana yang dapat digunakan untuk kegiatan operasional sehingga laba yang dihasilkan juga diharapkan semakin besar. Beban operasional pendapatan operasional memiliki pengaruh yang signifikan dan korelasi yang negatif dengan return saham. Semakin rendah BOPO, maka memberikan selisih keuntungan lebih banyak pada return saham suatu entitas, BOPO harus dipertimbangkan jika ingin mendapatkan keuntungan entitas dan memperbesar return yang diinginkan. Economic value added tidak tidak memiliki pengaruh yang signifikan return saham. EVA tidak dapat menggambarkan bagaimana perusahaan dapat memberikan pengembalian jika hanya terdapat penambahan dari segi ekonomi saja, tetapi tidak melalui laba operasional entitas itu sendiri. EVA juga dapat berguna apabila digabungkan dengan variabel lainnya, seperti return on asset dan return on equity.

Return on assets tidak tidak memiliki pengaruh yang signifikan return saham. ROA tidak berpengaruh pada return saham dengan kata lain bahwa kepemilikan aset perusahaan tidak dapat memastikan bahwa return saham yang dihasilkan juga akan besar. Capital adequacy ratio memiliki pengaruh yang signifikan dan korelasi yang negatif dengan return saham. Semakin besar biaya modal yang digunakan maka akan memperkecil biaya operasional yang nantinya akan menimbulkan keuntungan pajak dan akan meningkatkan return saham yang diterima oleh para pemegang saham.

Variabel moderasi yang digunakan dalam penelitian ini adalah Suku Bunga Bank Indonesia yang dapat memperkuat ataupun melemahkan hubungan antara variabel-variabel independen (loan to deposit ratio, beban operasional pendapatan oeprasional, economic value added, return on asset, dan capital adequacy ratio) dengan variabel dependen (return saham). Suku bunga Bank Indonesia dapat memperngaruhi hubungan antara loan to deposit ratio, beban operasional pendapatan operasional, dan capital adequacy ratio terhadap return saham. Hal ini menunjukkan bahwa variabel suku bunga Bank Indonesia dapat bertindak sebagai variabel moderasi untuk hubungan antara variabel-variabel tersebut.

Economic value added dan return on asset, variabel moderasi suku bunga Bank Indonesia tidak dapat bertindak sebagai variabel moderasi dalam pengaruhnya terdahap return saham. Suku bunga Bank Indonesia tidak mampu mempengaruhi hubungan antara economic value added dan return on assets dengan return saham. Hal ini mungkin disebabkan karena penggunaan suku bunga Bank Indonesia belum tepat digunakan sebagai variabel moderasi dalam mempengaruhi hubungan antara variabel-variabel ini.

\section{KESIMPULAN DAN SARAN}

Pada penelitian ini tidak tertutup kemungkinan terjadinya kesalahan yang menyebabkan hasil penelitian ini tidak dapat digeneralisasi. Hal-hal yang menjadi keterbatasan dalam penelitian ini, antara lain adalah sampel yang digunakan dalam penelitian ini terbatas pada emiten perbankan yang terdaftar di BEI dari tahun 2012-2016. Dan, proksi yang digunakan untuk variabel independen hanya terbatas pada loan to deposit ratio, pendapatan operasional beban operasional, economic value added, return on assets, dan capital adequacy ratio. 


\section{Ucapan Terima Kasih (Acknowledgement)}

Acknowledgement ini ditulis di bawah kesimpulan, sebelum referensi. Dalam acknowledgement ini disebutkan pihak-pihak utama yang mendukung penelitian ini, misalnya pemberi dana, instansi/orang pemberi data (dapat disamarkan apabila diperlukan anonim), asisten peneliti.

\section{REFERENSI}

Agus, Sartono. (2008). Manajemen Keuangan Teori dan Aplikasi. Edisi Keempat, Yogyakarta: BPFE.

Bambang Riyanto. (2001). Dasar-Dasar Pembelanjaan Perusahaan. Edisi Keempat, Yogyakarta: BPFE.

Brealey, Richard A. dan Myers, Stewart C. (2010). Principles Of Corporate Finance $\quad$ ( $7^{\text {th }}$ ed.). New York: The Mc Graw Hill Companies, Inc.

Brigham, Eugene F. dan Houston, Joel F. (2006). Dasar-dasar Manajemen Keuangan. Jakarta: Salemba Empat.

Brigham, Eugene dan Joel F Houston. (2001). Manajemen Keuangan II. Jakarta: Salemba Empat.

Corrado, C. J., dan B. D. Jordan. (2000). Fundamentals of Investment Analysis $\quad$ (4 $^{\text {th }}$ ed.). Singapore: Mc Graw-Hill.

Dendawijaya, Lukman. (2005). Manajemen Perbankan. Edisi Kedua, Jakarta: Penerbit Ghalia Indonesia.

Eisenhardt, Kathleem. (1989). Agency Theory: An Assesment and Review. Academy of Management Review.

Hartono, Jogiyanto. (2009). Sistem Teknologi Informasi. Yogyakarta: Andi.

Jogiyanto, H.M. (2010). Teori Portofolio dan Analisis Investasi. Edisi Ketujuh, Yogyakarta: BPFE.

Jones, Charles P. (2000). Investment: Analysis and Managemen ( $7^{\text {th }}$ ed.). John Willey and Sons, Inc.

Kasmir. (2012). Bank dan Lembaga Keuangan Lainnya. Edisi Revisi 2012. Jakarta: PT Raja Grafindo Persada.

Sipahutar, Agustinus Mangasa. (2007). Persoalan-persoalan perbankan Indonesia. Jakarta: Penerbit Praninta Jaya Mandiri.

Sugeng, Raharjo. (2010). Pengaruh Inflasi, Nilai Kurs Rupiah dan Tingkat Suku Bunga Terhadap Harga Saham di BEI. Surakarta: STIE.

Tasman, Aulia dan Havidz Aima. (2013). Ekonomi Manajerial dengan Pendekatan Matematis. Jakarta: Raja Grafindo Persada.

Taswan. (2010). Manajemen Perbankan Konsep, Teknik dan Aplikasi. Edisi Kedua, Yogyakarta : UPP STIM YKPN.

Tunggal, Amin Widjaja .(2008). Memahami Konsep Economic Value Added dan Value-Based Management. Penerbit Harvarindo.

Van Horne, James C. dan John M. Wachowicz, Jr. (1998). Fundamental Of Financial Management (10 ${ }^{\text {th }}$ ed.). New Jersey: Prentice Hall International, Inc.

Weston, Fred, J dan Brigham, F, Eugene. (1990). Dasar-dasarManajemen Keuangan. Edisi Kesembilan. Jakarta: Erlangga.

H. Miller, Merton dan Franco Modiglini. (1961). Dividend Policy, Growth, And The Valuation Of Shares. JSTORE. VOL: XXXIV. No. 4. 
Hobarth, Mag Lukas L.. (2006). Modeling the relationship between financial indicators and company performance - An empirical study for us listed companies. France: Dissertation Vienna University of Economics and Business.

Jensen, M, C., dan W. H. Meckling. (1976). Theory of The Firm : Managerial Behavior, Agency Cost and Ownership Structure. Journal of Financial Economics, 3, 82-137.

https://www.cnnindonesia.com/ekonomi/20150717174646-78-66952/bi-mulai-khawatirkanfenomena-peningkatan-kredit-macet

$\underline{\text { www.bi.go.id }}$ 